\title{
The Implementation of 6M Based Waste Management Module to Support Adiwiyata School Program
}

\author{
YuniKrisnawati \\ Muhammadiyah Metro Lampung University \\ Jl. Ki HajarDewantara No. 116 Iringmulyo, Kec.Metro Timur 3411 \\ E-mail: krisnawatilampung@gmail.com
}

Susilowati

Faculty of Mathematics and Science

State University of Malang, Jl. Semarang 5 Malang 65145

Mimien Henie Irawati Al Muhdhar

Faculty of Mathematics and Science

State University of Malang, Jl. Semarang 5 Malang 65145

Fathur Rachman

Faculty of Mathematics and Science

State University of Malang, Jl. Semarang 5 Malang 65145

Endang Budiasih

Faculty of Mathematics and Science

State University of Malang, Jl. Semarang 5 Malang 65145

Received: Dec. 2, 2014 Accepted: Feb. 10, 2015 Published: February 10, 2015

doi:10.5296/jse.v5i1.6725 URL: http://dx.doi.org/10.5296/jse.v5i1.6725 


\section{Abstract}

The present study aimed at improving the attitude and behavior of the students of SMPN 2 in waste management through the implementation of problem based learning ( $\mathrm{pbl}$ ) aided by $6 \mathrm{M}$ based waste management module. This study was a classroom action research (CAR), and the subjects of the study were 129 students. The problem based learning consisted of several stages, covering: the orientate the students to problems, ask the students to study, guide the students to individual and group investigation, develop and present the students' works which are supported by $6 \mathrm{M}$ based waste management module utilization that is able to change the students' attitude and behavior towards waste. The data of the students' attitude were collected through Likert scale, while the data of the students' behavior were collected through questionnaire. Other supported data were collected through observation. The data which were obtained from the attitude scale and the behavior checklist were analyzed by using N-gain score. The result of the study showed that the mean score of the students' attitude in cycle I was 79.8 increased into 88.5; while in cycle II increased from 78.0 into 92.0. The cycle I $\mathrm{N}$-gain score increased from 0.4 (moderate) to 0.6 (moderate). The result of the study showed that the mean score of the students' behavior in cycle I was 50.6 increased into 56.2; while in cycle II increased from 59.2 into 81.9. The cycle I N-gain score increased from 0.1 (low) to 0.6 (moderate). Those means showed that the implementation of Problem Based Learning (PBL) strategy aided by 6M based waste management module can improve the students' attitude and behavior in managing wastes.

Keywords: Problem Based Learning (PBL), 6M based waste management module, Attitude, behavior, Adiwiyata school 


\section{Introduction}

The people growth, activities changes, and behavior, as well as Indonesian consumption escalationpattern nowadays lead to the increasing amount of wastes. If this problem is not managed well, there will be a number of detrimental impacts for human being lives. The impact of waste for developed countries such as Netherland is different from that faced by developing countries such as Indonesia, since the former countries might get several advantages from wastes. According to Sunarto (2008) Netherlands is able to transform wastes into compost and electricity through incineration, recycling, and composting. The incineration is done by using high-tech equipment that reduce the air pollution, while the composting and recycling are done by separating the wet wastes, plastic wastes, and hazardous wastes before hands.Based on the citation, it can be seen that the key of success in developing a country that can manage wastes well and appropriately, do not merely rely on the government's role, but also all of the role of people all over the world.

Many action have been done to overcome the wastes problems in Indonesia, for example a study by Al-Muhdhar to rural and urban people. Al-Muhdhar (2003) states that the high of one's knoledge do not always reveal the highness of wastes management behavior. It is because of the inconsistency between knowledge, attitude, and behavior related to house-wastes management. Al-Muhdhar (2000) also states that the inconsistency between knowledge, attitude, and behavior depends on the basic education. The basic education on the level of primary and lower secondary education emphasizes the cognitive ability rather than affective or psychomotor ability. Even though the teachers try to insert the aspects of affective and psychomotor, the core of the subject is still the cognitive that causes the inconsistency between one's knowledge, attitude, and behavior. According to Al-Muhdhar (2003) attitude is a key factor that determines behavior of housewives in terms of managing wastes. Raven and Rubin in Al-Muhdhar (2003) stated that one's behavior is determined by several factors, one of which is attitude. Mar'at in Al Muhdhar (2003) explains that attitude is a hidden behavior, that has a tandency, that can predict the future behavior if the attitude is understood. The behavior supporting factors, based on Al-Muhdhar's (2012) study towards the way of urban and rural people in managing wastes, are economics, references sanction, norms, and researches or action. Economics factor related to the retribution and provident of land to manage wastes. Urban people might think that wastes problems is the responsibiliy of governance, thus they thihnk that wastes problems can be overcome by paying an amount of money to pay wastes retribution and some officers that collect and take wastes to wasteland. While rural people might think that waste problem is not a crucial problem since they can manage it by burning and burying the wastes. The forming of habit of $6 \mathrm{M}$ based management involving people is good for changing the behavior and habit in managing wastes directly and indirectly. Through the active involvement, it is expected that we can create three good conditions, either for individual or group, by separating wastes. The forming of subjective norms which are internalized in an individual, that causes one's awareness that wastes separation is a personal responsibility and if it is no done, each individual might feel guilty, and the forming of general norms that might make one feels that the act of separating wastes will get a beneficial value from others and if it is not done, each individual might get social sanction from others. 
Several studies related to $6 \mathrm{M}$ based waste management have been conducted previously, yet none of which was implemented in school level. Therefore, those studies are able to be used to support the Adiwiyata school program, particularly in managing wastes. Such practice in school is considered as one of ways to build a commitment by developing an environmental education program. School is a place to get various knowledge and norms, as well as ethics that functioned as the fundamental aspects in creating humans' welfare in a sustainable development. Through the goodness of school management, Indonesian sustainable development can be reached.UNESCO (2003) claimed that one way out of several ways that can be executed is through continuum development strategy which is integrated to education in every levels and types of education so that education might be the key agent of change in the implementation, and thus the stakeholders can applied the values through the learning activities that might lead to the improvement of the culture. One alternative considered as a potential way to support the Education for Sustainable Development (ESD) is environmental education. Nurjhani (2009) states that environmental education is important and thus has to be taught to children as early as possible so they understand and do not damage the environment.It is influenced by several aspects, like: (1) cognitive aspect. Environmental education functions to improve the environmental problem understanding, as well as improve the memory, implementation, analysis, and evaluation, (2) affective aspect. Environmental education functions to improve one's life setting acceptance, judgment, organization, and characteristics in relation to natural setting, (3) psychomotor aspect. Environmental education enables one to imitate and manipulate the interaction with the environment to improve the environmental-care culture, (4) interest aspect. Environmental education functions to improve children's interests. The common purpose of the environmental education based on Tbilisi conference in Rosyadi and Amin (2009) are: (1) explain the interrelation of economics, social, politics, and ecology care in both urban and rural areas; (2) give opportunity to each individuals to develop their knowledge, values, attitude, commitment, and capability needed to protect and preserve the environment; and (3) build individual, group, and society's new behavior into one towards environment. The expected purpose to be achieved are (1) knowledge, (2) attitude, (3) care,(4) skill, and (5) participation.

The observation carried out in SMPN 2 Malang in November 2013 resulted: (1) there was an environmental education subject which was a monolithic subject, however due to the absence of the target and dense curriculum in the implementation, the environmental education subject was omitted. Besides, the current curriculum, curriculum 2013, set teachers and students guidance book; (2) even though the school condition has already nice, the quality of environmental management either inside or outside the school is not yet good. The school does not have waste-collective facility in terms of the absence waste-separation system between wet waste (degradable) and dry waste (non degradable) also appropriate waste management; (3) although students know how to manage wastes well, their attitude and behavior towards wastes management is low. For example, there were a lot of students who still littering outside class, in their drawers, and school environment. They also tend to buy food at canteen rather than bring food from home; (4) the learning activities tend to be in form of lecturing, discussion, and question and answer; (5) most of the students prefer to study outside the class by doing practicum and alike. 
The wastes-less-care culture is a dreadful behavior that need to be resolved soon. $6 \mathrm{M}$ concept, consisting of reducing (mengurangi), reusing (menggunakankembali), replacing (mengganti), separating (memisahkan), recycling (mendaurulang), and composting (mengomposkan) is considered as a good notion to overcome such behavior. $6 \mathrm{M}$ concept was initiated by $\mathrm{Al}$ Muhdhar (1998) which consisted of several acts, namely reducing (mengurangi), reusing (menggunakankembali), replacing (mengganti), separating (memisahkan), recycling (mendaurulang), and composting (mengomposkan). Al-Muhdhar (1998) stated that reducing is an effort to decrease the amount of wastes. Reusing is an act of make use of one thing for several times. Replacing means change a certain product to another product. Separating refers to an act of differing the types of wastes (wet wastes and dry wastes). Recycling means reuse wastes after being processed. Composting refers an act of processing household wastes into compost. Al-Muhdhar (1998) suggests several ways of reducing, they are: 1) shop carefully, in terms of: a) bring shopping bag or box when shop, b) make a shop list so we only buy what we really need, c) avoid things that are over wrapped, d) choose refillable products (such as ballpoint). e) if it is a wrapped product, make sure the wrap is recyclable or reusable, f) reduce the use of products that are easily get dumped, such as tissue paper, $g$ ) if there are size choices, choose the big size, and reject plastic bags for one thing purchase; 2) cook food from home in order to avoid fast food consumption; 3) create cards or gifts ourselves from waste product of our daily activities, rather than buying; 4) rent things instead of buying if possible. Al-Muhdhar (1998) also suggests that reusing can be done through: 1) reuse plastic bottles or plastic glasses, 2) if there are many unused things, it is better to hand over them to others to use, 3) reuse another side of half-sided used papers for: drawing paper for children, letter drafts, children's worksheets, shop lists, phone memos, children's toy, etc., 4) open envelope carefully so that it can be used again, and 5) reuse plastic bags and keep them well to be used in other occasions. Al-Muhdhar (1998) explains that replacing can be performed by replacing things or foods wrap into reusable and recyclable wrap, or compost the wrap, and put it in separate cans. Al-Muhdhar (1998) suggests that separating is an act of differing household wastes between wet wastes and dry wastes. Wet wastes are decomposable wastes, like food, while dry wastes are indecomposable goods, like paper, plastic, metal, glass, rubber, cloth, battery, and others. The practical ways to separate household wastes are: 1) provide two kinds of trash cans, 2) separate wet wastes and dry waste when cooking, and 3) put the types of wastes into the appropriate provided trash cans. Al-Muhdhar (1998) says that the act of separating wastes facilitates the recycle process for the recyclable wastes are not mixed with other wastes. Waste recycle is an act of reusing wastes through certain processes. It can be done to paper, plastic, can, glass, etc. Al-Muhdhar (1998) states that composting household wastes can be performed by burying them with wet wastes. Wet wastes are put into a hole, and added with soil and worms to make the process of decomposing faster. After the wastes are decomposed and become fertilizer, it is ready to be sold or used to fertilize plants.

This study was performed in school level. Therefore, the way to deliver the materials related to $6 \mathrm{M}$ based waste management was not similar to the way to deliver the material to the society. Based on the observation result which was conducted in SMPN 2 Malang, it was used a learning strategy to reach the goal of the study in changing the students' attitude and behavior towards wastes. The strategy used was Problem Based Learning aided by $6 \mathrm{M}$ waste 
management module. The advantages of module are: (1) it can maximally improve the teaching and learning activities, (2) it makes the students participate more actively for they are given a number of problems to be solved, (3) it gives direct responses so that the students know their performance values, (4) it leads the students performances due to its goals, and (5) the students' works are not tied to the teacher's quality since the learning materials have already set in the module (Nasution, 2000). He also adds that there are weaknesses of module for learners need to be straight the learning schedule so that they have to be able to arrange their own time, force themselves to study, and shield themselves from the willingness to be idle. Students who tend to have teacher-centered learning are likely more passive and might be difficult to adapt the new learning way. These weaknesses can be integrated to the best fit learning strategy.

Based on learning strategies involved in curriculum 2013 and the students' interests as well as learning by doing aspect, it is expected that the Problem Based Learning $(P B L)$ facilitate students to enhance their attitude and behavior related to wastes management. Poedjiadi (2005) states that besides facilitate the knowledge construction, contextual learning help students to better their affective aspect such as develop their ethics so that there will be intrinsic and permanent behavior changes. Pannen, et al. (2001) claim that Problem Based Learning strategy good at: (1) focusing the learning on meaning, instead of fact (deep surface learning), (2) enhancing the students' ability to initiate, (3) developing skills and knowledge, (4) developing interpersonal skill and group dynamics, (5) developing self-motivated perceived, in case of the learning process the students are free to explore the material with peers and teacher's guidance so that the learning environment becomes fun and students will be motivated to learn, and (6) creating students-facilitator's relationship, instead of students-teacher relationship.

The effectiveness of the implementation of Problem Based Learning aided module is supported by previous studies. Suardana (2006) suggests that the implementation ofProblem Based Learning enhance the students' ability in solving problems and students' learning outcomes. Most students gave positive responses and thus he expected that the Problem Based Learning aided module can be implemented to physics and chemistry subjects. Purnomo's (2009) study results that lecturing activity through Problem Based Learning strategy aided module enhance the students' activities and independence, also enhance the students' metrology learning and learning outcome. Based on the above motives, it is expected that the implementation Problem Based Learning aided 6M waste management module enhance the students' attitude and behavior to success the achievement of Adiwiyata school program of SMPN 2 Malang.

\section{Methodology}

The present study was a classroom action research (CAR) by implementing Problem Based Learning (PBL) aided by $6 \mathrm{M}$ waste management module. This study was conducted in 2 cycles in which consist of 4 components, namely planning, implementing/acting, observing, and reflecting. The subjects of the study were 129 first grade students of second semester of SMPN 2 Malang academic year 2013/2014. The classes included in this study were class VII 
A and VIIB with the 33 students, class VII I with 32 students, and class VII J with 31 students.

The measurement of the affective aspect was not as easy as that of the cognitive aspect. The measurement of the affective aspect could not be done anytime (in terms of formal measurement) since the changing of the students' behavior did not change at anytime. It takes some times to change one's attitude changes (Arikunto, 2009). Affective questions did not ask for correct or incorrect answers, yet they particularly related to ones' interest, attitude, and value internalization (which are divided between maximum performance and typical performance attitude by Cronbach) (Cronbach, 1970). In this study, Likert scale was used to measure the students' attitude. The scale was arranged in form of statements and were followed by five responses representing various meanings, viz. very agree, agree, neutral, disagree, very disagree. The attitude scale was used as a test and aimed at measuring whether there was a change of the students' attitude in terms of waste management before and after learning activities. The data obtained were analyzed by using N-Gain score. The other attitude aspects which were measured were the students' campaign, and the recycled product assessment. The measured aspect from campaign activities was the students' attitude (bravery, cooperation, persuasion, and willingness) when campaigning. The observer brought a camera to record the students' campaign activity. The records were analyzed and assessed. The products which were measured from the recycled activities were the result of the recycling performed by the students. Teachers instructed the students of each groups to create a recycled product from unused materials. The teachers observed and then assessed based on the aspects needed.

The measurement of the psychomotor aspect was done to the students' learning outcome in terms of performance; yet such measurement was integrated or started from the cognitive aspect at once. The instrument used to measure the students' skill was in form of matrix. The downward line expressed aspect in detail (skill) which would be measured, rightward expressed the score achieved (Arikunto, 2009). The matrix was used to measure the students' activities when they practiced takakura composting. The teachers used practical assessment sheets during the observation, which was conducted when the students were practicing takakura composting. The psychomotor skill or the students' behavior was measured by using Self Evaluation technique in form of checklist in which there was three options, namely always, seldom, and never. Similar to the attitude measurement, a pretest and a posttest were administered to measure the students' behavior in managing waste before and after the classroom learning.

The data from the Likert scale and checklist of the students' behavior from each cycle were analyzed by using the mean scores and the $\mathrm{N}$-gain score. The normalized gain score $(\mathrm{N}$-gain score) is the different between posttest score and pretest score divided by the different between ideal score and pretest score (Meltzer, 2010), in which gain score showed the enhancement after the learning. The normalized gain score $\langle\mathrm{g}>$ is also a better indicator in showing the effective level of action rather than score or posttest achievement. The normalized gain score level is categorized into three, viz. $\mathrm{g}-$ high if $(<\mathrm{g}>)>0.7$; $\mathrm{g}-$ moderate if $0.7 \geq(<\mathrm{g}>) \geq 0,3$; dan $\mathrm{g}-$ lowif $(<\mathrm{g}>)<0,3$. 


\section{Results}

The result of the study was divided into two sections, namely affective section and psychomotor section.

\subsection{Affective Section}

The analysis result of the attitude pretest and posttest in cycle I and cycle II using N-gain score enhanced. The posttest mean of cycle II was higher than posttest mean of cycle I, where the mean of cycle II was 92.0 and the mean of cycle I was 91.0. The N-gain score of cycle I was 0.4 (moderate) enhanced onto 0.6 (quite good) on cycle II. The mean score of overall attitude test of cycle I and cycle II using $\mathrm{N}$-gain score is presented in Table 1.Campaign activity is an act of campaigning posters with theme of $6 \mathrm{M}$ action to ask all school community to be care to environment. The lowest campaign mean score was on persuasion aspect. The overall campaign mean score is presented in Table 2.Besides doing a campaign, the students were taught to manage wastes through recycling the unused things in school and at home. The recycle mean score is presented in Table 3.

Table 1. The Overall Attitude Mean Score of Cycle I and Cycle II

\begin{tabular}{lllll|llll}
\hline & \multicolumn{4}{c|}{ CYCLE I } & \multicolumn{4}{c}{ CYCLE II } \\
\cline { 2 - 9 } Means & Pretest & Posttest & Different & N-gain & Pretest & Posttest & Different & N-gain \\
\cline { 2 - 8 } & 79,8 & 88,5 & 8,7 & 0,4 & 78,0 & 92,0 & 14,0 & 0,6 \\
\hline
\end{tabular}

Table 2. The Class Campaign Mean Score

\begin{tabular}{|c|c|c|c|c|c|c|}
\hline \multirow{2}{*}{ Aspects being Assessed } & \multirow{2}{*}{$\begin{array}{l}\text { Max. } \\
\text { Score }\end{array}$} & \multicolumn{4}{|c|}{ Class } & \multirow{2}{*}{ Means } \\
\hline & & VII A & VII B & VII I & VII J & \\
\hline Bravery & 25 & 20,3 & 21,6 & 24,0 & 25,0 & 22,7 \\
\hline Cooperation & 25 & 19,8 & 20,3 & 21,3 & 21,3 & 20,7 \\
\hline Persuasion & 25 & 19,5 & 21,0 & 18,8 & 19,4 & 19,7 \\
\hline Willingness & 25 & 23,3 & 20,1 & 24,0 & 24,0 & 22,8 \\
\hline Total & 100 & 82,8 & 83,0 & 88,1 & 89,6 & 85,9 \\
\hline
\end{tabular}


Table 3. The Class Recycle Mean Score

\begin{tabular}{|c|c|c|c|c|c|c|c|}
\hline \multirow{2}{*}{ No } & \multirow{2}{*}{ Aspects } & \multirow{2}{*}{ Max. Score } & \multicolumn{4}{|c|}{ Class } & \multirow{2}{*}{ Means } \\
\hline & & & VII A & VII B & VII I & VII J & \\
\hline 1 & Planning & 20 & 20 & 20 & 20 & 20 & 20,0 \\
\hline \multirow{4}{*}{2} & Process & & & & & & \\
\hline & a. Preparation & 20 & 12,8 & 13,3 & 15,3 & 14,4 & 14,0 \\
\hline & b. Technique & 10 & 10 & 10 & 10 & 10 & 10,0 \\
\hline & c. Safety & 10 & 10 & 10 & 10 & 10 & 10,0 \\
\hline \multirow{4}{*}{3} & Result & & & & & & \\
\hline & a. Aesthetic & 20 & 14,4 & 15,6 & 15,6 & 17,2 & 15,7 \\
\hline & b. Innovation & 20 & 14,4 & 15,6 & 15 & 16,1 & 15,3 \\
\hline & Total Score & 100 & 81,6 & 84,5 & 85,9 & 87,7 & 85,0 \\
\hline
\end{tabular}

\subsection{Psychomotor Section}

The result of actual behavior pretest and posttest analysis of cycle I and cycle II using N-gain score is presented in Table 4. Besides obtaining from the actual behavior pretest and posttest, the psychomotor score were also obtained from the students' performance measurement which was observed from the takakura composting practicum. The each class practicum mean score is presented in Table 5.

Table 4. The Overall Actual Behavior Mean Score

\begin{tabular}{ccccc|cccl}
\hline \multirow{4}{*}{ Means } & \multicolumn{4}{c|}{ CYCLE I } & \multicolumn{4}{c}{ CYCLE II } \\
\cline { 2 - 8 } & Pretest & Posttest & Different & $\begin{array}{l}\text { N-gain } \\
\text { score }\end{array}$ & Pretest & Posttest & Different & $\begin{array}{l}\text { N-gain } \\
\text { score }\end{array}$ \\
\cline { 2 - 8 } & 50,6 & 56,2 & 5,6 & 0,1 & 59,2 & 81,9 & 22,7 & 0,6 \\
\hline
\end{tabular}


Table 5. Each Class Practicum Mean Score

\begin{tabular}{|c|c|c|c|c|c|}
\hline \multirow{2}{*}{ Aspects } & \multirow{2}{*}{ Max. Score } & \multicolumn{4}{|c|}{ Class } \\
\hline & & VII A & VII B & VII I & VII J \\
\hline 1.1 Tools and materials preparation & 10 & 9,3 & 9,7 & 9,7 & 10 \\
\hline 1.2 Safety tools utilization & 5 & 5 & 5 & 5 & 5 \\
\hline 2.1 Tools and materials utilization & 15 & 4,3 & 4,7 & 4,7 & 5 \\
\hline 2.2 Action & 15 & 13 & 14,2 & 14,2 & 14,7 \\
\hline \multicolumn{6}{|l|}{$\begin{array}{l}\text { 2.3 Willingness, observation skill, drawing, and } \\
\text { identification }\end{array}$} \\
\hline a. Focus on the activities & 3 & 3 & 3 & 3 & 3 \\
\hline b. Actively involved in the practicum & 3 & 3 & 3 & 3 & 3 \\
\hline c. Observe the practicum result meticulously & 10 & 6,5 & 5,3 & 5,5 & 5,4 \\
\hline d. Interpret the observation correctly & 5 & 5 & 5 & 5 & 5 \\
\hline e. Present the data systematically and communicatively & 3 & 2,7 & 2,8 & 2,8 & 3 \\
\hline f. Data analysis & 13 & 8,3 & 9 & 8,7 & 9 \\
\hline g. Draw conclusions based on the objectives & 8 & 8 & 8 & 8 & 8 \\
\hline h. Cooperation & 3 & 3 & 3 & 3 & 3 \\
\hline i. Interested in the activity & 3 & 3 & 3 & 3 & 3 \\
\hline a. Clean the utilities & 3 & 3 & 3 & 3 & 3 \\
\hline b. Clean the practicum place & 3 & 3 & 3 & 3 & 3 \\
\hline c. Put the practicum utilities to the proper place & 3 & 3 & 3 & 3 & 3 \\
\hline TOTAL SCORE & 100 & 83,1 & 84,7 & 84,6 & 86,1 \\
\hline
\end{tabular}

\section{Discussion}

4.1 The Students' Attitude towards Wastes Management afterthe Implementation of Problem Based Learning Strategy Aided 6M Waste Management Module

Based on the descriptive analysis of the findings, it was found that the mean score between the pretest and posttest enhanced. The N-gain score analysis also revealed that the implementation of Problem Based Learning (PBL) aided 6M waste management module of the cycle I to that of the cycle II enhanced even though the enhancement was categorized as moderate (seen from the $\mathrm{N}$-gain score, that was 0.4 to 0.6 ). This result could not be separated from Azwar's (1995) definition of attitude that attitude is a perceive evaluation and potential tendency to react, which resulted from the interaction between cognitive, affective, and desire components during understanding, perceiving, and acting towards a particular object. People were not born completed with attitude and view instead they were formed 
along with the development during the interaction, where they react to form a certain attitude towards various psychological objects. It verified the fact that in order to build the students' attitude in relation to wastes management, we need to conduct campaign activity. It is because the students are taught to interact with their environment, which lead to creation of personality that can manage wastes, since his/her ego and emotion requires self-acknowledgement.

Cognitive component is a component consisting of knowledge. This knowledge builds particular belief and view towards attitude. Affective component is a component related to happiness or unhappiness, that it is evaluative in nature. This is closely related to value system of the attitude owner. Desire component is an attitude component in form of one's readiness to behave in relation to a condition. These theoretical basics support the role of knowledge aspect, in this case cognitive aspect which is one of aspects in building one's attitude. Thus, it is normal when a group of high academic people who is believed possess wider knowledge score higher in attitude compared to those of low academic people.

Based on the above mentioned point of views, it can be inferred that changing and forming individual's attitude can be done through component cognitive, affective, and desire. According to Walgito (2003)transferring knowledge, delivering opinion, showing attitude and alike, might change the cognitive component, it automatically will change the affective component as well, and in the end one's attitude changes. The affective component contributes through such thing like feeling or emotion, so as the feeling changes the attitude will also change. Rosenberg (in Walgito, 2003) suggested that affective component will always be related to cognitive component, and this is quite consistent. Rosenberg created attitude scale and argued that there is consistent relationship between cognitive components. It means that when a person act positively towards a particular object, the cognitive index is also high, vice versa. Al Muhdhar (2003) claims that the key factors determine one's attitudes are the number of information media possessed and the active participation in the social organization. It also happened to students when they learn and finish tasks related to environmental problems, it will extend their knowledge so does their attitude.

The results of this study is consistent with such of the previous study conducted by Alkas (2007) in chemist environmental learning in which there was a positive correlation between the chemist environmental outcomes and the environmental awareness level of the students of chemistry department of Faculty of Mathematics and Science State University of Malang. The result of Al Muhdhar's (2003) study shows that there is knowledge contribution towards the society's attitude toward wastes management. Such result was verified by Setyowati's (2011) that wastes management education through the implementation of science, technology, and society based wastes management multimedia module enhanced the students' knowledge, attitude, and behavior. Other than that, Santoso's (1993) study concluded that the higher the environmental knowledge subject achievement, the more positive the students' attitude towards the environment. Amongst variables learning span, grade point, and environmental knowledge course span, the second (grade point) variable was the most related to one's attitude towards environment. Is was consistent with previous research by Patawari (1989) 
who inferred that Biology leaning in SMAN Sengkang, Wajo, South Celebes was generally influenced to the students' attitude towards environmental preserve.

\subsection{Students' Behavior towards Wastes Management after the Implementation of Problem Based Learning Strategy Aided 6M Waste Management Module}

Based on the result of descriptive analysis it was known that the mean score between the pretest and posttest enhanced. The posttest score of cycle II enhanced to 81.9 from the initiate mean of cycle I 56.2. It showed that there was an enhancement in the students' behavior in managing wastes. In relation to behavior, Skiner (1976) divided behavior into two, innate behavior and operant behavior. Non-reflective behavior or operant behavior is controlled by human's brain. Thus after human receptor receives stimulus, it is continued to brain as the core neuro controller, as a consciousness, then human can create response through effector. This process is called psychological process. Human's behavior or activities based on this psychological process is called psychological activities (Branca, 1964 in Walgito, 2003). For human, such psychological behavior is quite dominant, since most of human's behavior either operant behavior (Skinner, 1976) or psychological behavior (Branca, 1964) are formed, learnt, and controlled behavior, so that it can be changed through learning process. Therefore, in order to change the behavior of students of SMPN 2 Malang towards wastes management it is necessary to be included in the teaching and learning activities.

The result of the study related to environmental management know-how cannot be separated from Gagne's statement in Depdiknas (2003) that there are two conditions that might optimized the skill learning outcome, they are internal and external condition. The internal condition can be encouraged by recalling the learnt sub-skills and recalling the mastered procedures or stages, while the external condition can be encouraged by giving verbal instructions, graphics, demonstrations, practice, and feedback. Other view from school of cognitive (in Walgito, 2003) that is viewing individual behavior is a response from stimulus, yet there is capability inside individuals to make decisions. It means that in active position, each individual can make a decision. The relation of stimulus and response do not directly occur automatically, instead each individual should decide his/her own behavior. Based on that, the implementation of Problem Based Learning (PBL) strategy aided 6M waste management module facilitated the students to learn. The students are not only learn abstractly but also concretely through exploration and practicum in syntax of the PBL strategy so that they can decide which behavior should they take; Whether the students will implement the $6 \mathrm{M}$ daily or merely add some information.

Krech and Crutchfield (in Walgito, 2003) stated that there is a relation between attitude and behavior. People's behavior will be based on their attitude. Myers (in Walgito, 2003) argued that behavior is things that will much be influenced by environment. Behavior and attitude have a mutual interaction, influence one another. Hence, it can be inferred that basically, Myers's view tends to the existence of the interrelation between attitude and behavior, where those two aspects influence one another. In line with Azwar's (2001) opinion that one's attitude towards a particular object, in this case wastes management which is related to his/her knowledge and attitude, is supporting or non-supporting act towards that object. Thus, 
it can be assumed that even though respondents got higher knowledge score, it did not mean that he/she has better attitude towards waste management. Based on the data obtained, it revealed that most of the students who possess higher cognitive and attitude tend to have high level of behavior, yet there were also students who have high cognitive and attitude but their behavior was categorized as low. Again, these phenomena were influenced by intrinsic and extrinsic motivation factors of the students.

The behavior supporting factors from Al Muhdhar's (2012) study towards how to manage wastes of urban and rural people are done through several factors, namely economics, idol, penalty, norms, and research or action. The economics factor related to retribution and the facility provided to manage the household wastes. Urban people might think that wastes problems is government responsibility so they might think that paying amount of money (retribution) will be enough and through the cleaning service who collect and take the wastes to waste-space. Whereas for rural people, wastes problems are mostly thought as an easy problem since they can manage their own household wastes by burning them down or buried them out. The implementation of $6 \mathrm{M}$ in managing wastes by involving influenced people mediates people's behavior or habit in changing behavior or habit in managing wastes either directly or indirectly. Through this active involvement, it is expected that there will be three conditions, either individual condition or society condition, where there is habit formation in separating wastes. The formation of internalized subjective norms within individuals, until there is awareness that separating wastes is each person responsibility and if someone absence he/she will feel guilty, as well as the formation of norms which cause that each wastes separation valued more in their society and if someone absence he/she will get penalty from the society.

According to Al Muhdhar (2003), the high knowledge does not always show the highness of individual actual behavior in managing wastes. It is because of the inconsistency of knowledge, attitude, and actual behaviortowards household wastes management. Raven and Rubin (1983) stated that an individual behavior is influenced by: (1) one's willingness to do, (2) the willingness is affected by his/her belief towards consequences of the action as well as the advantages for him/herself, (3) the values are influenced by his/her belief towards the expectation and idol as well as the motivation, (4) the motivation influences to individual subjective norms to do a particular act. According to Al Muhdhar (2000) the inconsistency between knowledge, attitude, and behavior is based on the basic education. The basic education on the level of elementary school and junior high school emphasize the students' cognitive ability, neither the students' affective nor psychomotor ability yet. The key point is cognitive aspect which causes the inconsistency between one's knowledge, attitude, and behavior. Al Muhdhar (2003) informs that attitude is a key factor that determines the actual behavior, in this case is housewives' behavior in managing wastes. Raven and Rubin (1983) claimed that an individual behavior is determined by several factors, viz. attitude. Mar'at (1982) stated that attitude is an introvert behavior, tendency, and willingness that can be guessed which occurs when the attitude is known. Mulyadi, Siregar, and Saam (2010) said that the society overall behavior towards wastes management in Tembilahan is categorized as moderate; it was influenced by the low education factor and the work of the people which 
affect their incomes. Based on those cited work, it can be concluded that one's behavior is based on his/her attitude and behavior.

Other judgments to facilitate the formation of behavior are authentic judgment of recycling products and takakura composting. On the practicum assessment, the lowest aspect mean score was in data analysis. The students have not been able to link, interrelate between the data obtained. It is in line with Piaget (in Ormrod, 2009) statement that the concrete operation stage for children between 6 or 7 years old to 11-12 years old. He stated that in concrete operations stage, the children thinking process is more organized to the mental systems - operations - which ease them to think more logically before. Even though the students show that the concrete operations indicated by logical thinking, their cognitive development is not complete yet. For example, most students feel difficult in understanding abstract notions, and facing the huge amount of items, the hypothesis or the variables.

Based on the students recycling products, most of them are difficult in deciding innovation. This is, again, related to the individual's creativity. Creativity is not a mono entity that can be growth easily through several simple exercises, where creativity has different form in the distinct content, and the students tend to be more creative in a particular of subjects (Ormrod, 2009). This citation claimed that creativity is natural interest possessed by each person. When in a person have his/her own interests, it is better if they do things they mastered at.

\section{Conclusions and Suggestions}

\subsection{Conclusions}

Based on the data analysis and the discussion before hands, it can be concluded that: (1) the implementation of Problem Based Learning aided 6M waste management module can enhance the students' waste management attitude. The mean score of the attitude test result on cycle I increased from 79.8 to 88.5 , while on cycle II increased from 78.0 to 92.0. The $\mathrm{N}$-gain score also increased from 0.4 to 0.6 (which was categorized as quite good), (2) the implementation of Problem Based Learning aided 6M waste management modulecan enhance the students' waste management behavior. The mean score of the behavior test result on cycle I increased from 50.6 to 56.2 , while on cycle II increased from 59.2 to 81.9. The $\mathrm{N}$-gain score also increased from 0.1 to 0.6 (which was categorized as quite good), (3) the contributions from this study are: a) for the researchers, it can be used as the basic to conduct future research through different innovative methods and can be implemented to other schools, b) the module used in this study might provide detail operational information related to the model of $6 \mathrm{M}$ based waste management learning because the teachers' and the students' module were arranged based on the criteria of good module, so that it enables the teachers and the students in conducting the waste management learning theoretically and practically,c) it can improve the teachers' and the students' behavior in managing wastes, d) it gives indirect contributions to the goverment to support the Adiwiyata school program.

\subsection{Suggestions}

Based on the result of the study, it can be suggested that: 


\section{Macrothink}

Journal of Studies in Education

ISSN 2162-6952

2015, Vol. 5, No. 1

1. Other studies related to the implementation of various models of innovative learning aided by $6 \mathrm{M}$ based waste management.

2. Other studies in a wider scale are conducted in East Java Province.

3. Quasi experimental researches were conducted to examine the effect of various models of other innovative learning saided by $6 \mathrm{M}$ based waste management towards the students' learning outcomes of knowledge, attitude, and behavior.

\section{References}

Alkas, T. R. (2007). Pengaruh Penerapan Model PBL pada Pembelajaran Kimia Lingkungan dalam Meningkatkan Hasil Belajar dan Kesadaran Lingkungan Mahasiswa Jurusan Kimia FMIPA UM Malang.Unpublished Dissertation. Malang: Universitas Negeri Malang.

Al Muhdhar, M.H.I. (1998). KeterkaitanantaraFaktorSosial, FaktorEkonomi, FaktorBudaya, Pengetahuan, danSikapIbu-ibuRumahTanggadalamPengelolaanSampahRumahTangga, denganManifestasiPerilakuIbu-ibuRumahTanggadalamPengelolaanSampahRumahTangga. Unpublished Dissertation. Malang: PPs UM.

Al Muhdhar, M.H.I. (2000).KetidakkonsistenanantaraPengetahuan, SikapdanManifestasiPerilakuIbu-IbuRumahTanggadalamPengelolaanSampahRumahTangga di Kota Surabaya.JurnalPenelitianKependidikan, 10 (2): 166-178.

Al Muhdhar, M.H.I. (2003). KontribusiFaktorSosial, Ekonomi, Pengetahuan, danSikapterhadapManifestasiPerilakuIbu-IbuRumahTanggadalamPengelolaanSampahRumah Tangga di DukuhSanan, KecamatanBlimbing, Kota Malang. Jurnal Pendidikan Nilai (KajianTeori, Praktik, DanPengajarannya), 10(1), 105-116.

Al Muhdhar, M.H.I. (2003). KeterkaitanFaktorSosial, Ekonomi, Pengetahuan, danSikapterhadapManifestasiPerilakuIbu-IbuRumahTanggadalamPengelolaanSampahRumah Tangga di Kota Surabaya.JurnalIlmuPendidikan, 10 (2): 174-189.

$\begin{array}{lllll}\text { Al Muhdhar, } & \text { M. } & \text { H. } & \text { I. (2012). }\end{array}$ MengubahParadigmaMasyarakatdalamPengelolaanSampahRumahTanggamelaluiPembuday aan 6M. Malang: State University of Malang (UM Press).

Azwar, S. (1998). SikapManusia: TeoridanPengukurannya. Yogyakarta: PustakaPelajar.

Depdiknas.(2003). PenulisanModul. Jakarta: DepartemenPendidikanNasional.

Meltzer, D.E. (2010).Normalized Learning gain: A Key Measure Of Student Learning. Lowa: Department of Physics and Astronomy: Iowa State University.

Mulyadi, A., Siregar, SH., \& Saam, Z. (2010).PerilakuMasyarakatdanPeran Serta Pemerintah Daerah dalamPengelolaanSampah di Kota Tembilahan. Journal of Environmental Science, 2(3), 147-162.

Nasution, S. (2000). BerbagaiPendekatandalam Proses Belajar\&Mengajar. Jakarta: BumiAksara. 
Nurjhani, M. (2009). Bahan Belajar Mandiri 6 (Pendidikan Lingkungan di SD). http://file.upi.edu/Direktori/DUAL...SD/BBM_6.pdf. Accessed on $17^{\text {th }}$ Desember 2013 pukul 04.00 WIB.

Mar'at. (1982). SikapManusiaPerubahansertaPengukuran.Jakarta: Ghalia Indonesia.

Ormrod, J. E. (2008). PsikologiPendidikanMembantuSiswaTumbuh Dan Berkembang (Jilid 2, EdisiKeenam). Translated by Indianti, W., Septiana, E., Saleh, A. Y., \& Lestari, P. 2009. Jakarta: Erlangga.

Pannen, P., Dina M. \&Mestika, S. (2001). KonstruktivismedalamPembelajaran. Jakarta: Diknas.

$\begin{array}{lllll}\text { Patawari, } & \text { A. } & \text { A. } & \text { L. } & \text { M. }\end{array}$ StuditentangImplikasiPengajaranBiologidalamHubungannyadenganPengembanganSikapterh adapPelestarianLingkunganHiduppadaSiswa SMA NegeriSengkangKabupatenWajo Sulawesi Selatan.Unpublished Thesis. Malang: Program PascasarjanaUniversitasNegeri Malang.

Poedjiadi, A. (2005).SainsTeknologiMasyarakat.Bandung: PT.Remaja

Purnomo, E. (2009).Implementasi Problem Based Lerning (PBL) BerbantuanModuldalamUpayaMeningkatkanKualitasperkuliahanMetrologi. Yogyakarta: FakultasTeknikUniversitasNegeri Yogyakarta.

Raven, B.H. \& Rubin, J.Z. (1983).Social Psychology. New York: John Wiley \& Sons.

Rosyadi, H. dan Amin.(2009). IntegrasiPendidikanKependudukandanLingkunganHidup (PKLH) pada Mata Pelajaran IPS di SMP.Region, 1 (3): 1-11.

Santoso, H. (1993). HubunganPendidikanBiologiDenganSikapTerhadapLingkunganHidup. Unpublished Thesis. Malang: Program PascasarjanaUniversitasNegeri Malang.

Setyowati, E. (2011). Pengembangan Modul Multimedia PengelolaanSampahBerwawasanSainsTeknologiMasyarakatsebagaiUpayaPeningkatanPenget ahuan, Sikap, danPerilakuPesertaDidik SMA.Unpublished Dissertation. Malang: Program PascasarjanaUniversitasNegeri Malang.

Suardana,

I.N. (2006).PenerapanstrategiPembelajaranBerbasisMasalahdenganPendekatanKooperatifBerbant uanModuluntukMeningkatkanKualitasProses danHasilBelajarMahasiswapadaPerkuliahan Kimia Fisika I. JurnalPendidikandanPengajaran IKIP NegeriSingaraja, 39(4), 751-768.

Sunarto.(2008). Belajar Cara Belanda Mengelola Sampah. Malang: Universitas Muhammadiyah Malang.

Walgito, B. (2003).PsikologiSosial. Jakarta: CV. Andi Offset. 